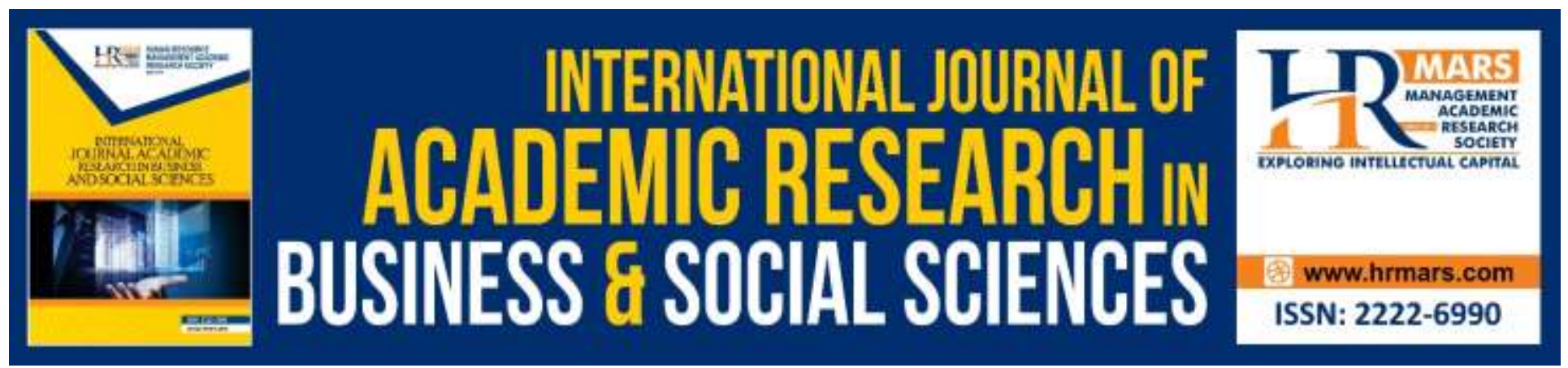

\title{
Does Contract Employment Affect the Behaviour of Employees?
}

Daisy Ofosuhene, Zeinab Sammo

To Link this Article: http://dx.doi.org/10.6007/IJARBSS/v10-i5/7228

DOI:10.6007/IJARBSS/v10-i5/7228

Received: 08 March 2020, Revised: 14 April 2020, Accepted: 20 April 2020

Published Online: 21 May 2020

In-Text Citation: (Ofosuhene \& Sammo, 2020)

To Cite this Article: Ofosuhene, D., \& Sammo, Z. (2020). Does Contract Employment Affect the Behaviour of Employees? International Journal of Academic Research in Business and Social Sciences, 10(5), 557-574.

Copyright: (C) 2020 The Author(s)

Published by Human Resource Management Academic Research Society (www.hrmars.com)

This article is published under the Creative Commons Attribution (CC BY 4.0) license. Anyone may reproduce, distribute, translate and create derivative works of this article (for both commercial and non-commercial purposes), subject to full attribution to the original publication and authors. The full terms of this license may be seen

at: http://creativecommons.org/licences/by/4.0/legalcode

\section{Vol. 10, No. 5, 2020, Pg. 557 - 574}

Full Terms \& Conditions of access and use can be found at http://hrmars.com/index.php/pages/detail/publication-ethics 


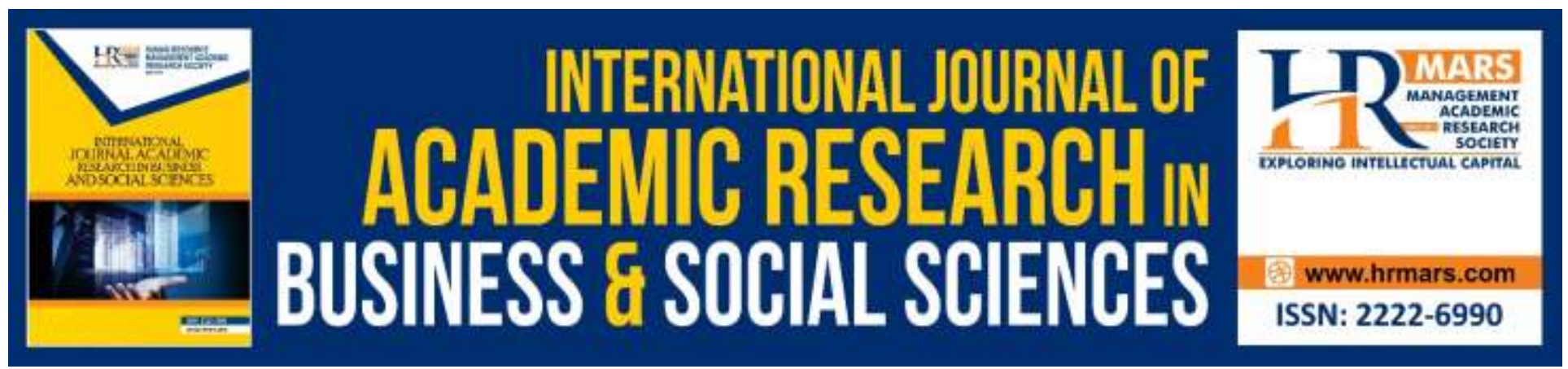

\title{
Does Contract Employment Affect the Behaviour of Employees?
}

\author{
Dr. Daisy Ofosuhene
}

University of Cape Coast, College of Distance Education, Arts and Social Science Programmes, Cape Coast, Ghana.

Email: dofosuhene@ucc.edu.gh.

\section{Zeinab Sammo}

University of Cape Coast, College of Distance Education, Department of Business Studies, Cape Coast, Ghana.

\begin{abstract}
This study sought to examine the effect of contract employment on the behaviour of employees at the Ghana Shippers Authority, in term of their commitment, work initiative and job satisfaction. The study was cross-sectional in nature, utilizing the quantitative approach. The study adopted the descriptive design. Using a simple random sampling technique, this research sampled 142 employees to participate in the research. A structured questionnaire was used to collect data from the respondents, which was analysed with the use of Pearson Product Moment Correlation, a Simple Linear Regression and an Independent T-Test. The reliability of the instrument was tested with the use of Cronbach's Alpha reliability co-efficient. The study found that contract employment had a moderate relationship with all the variables under study and a weak effect on the variables. Again, the study did not find any significant differences between the behaviour of contract employees and permanent employees. This findings call for further studies to identify the reasons for differing findings in empirical literature, with regards to this subject.

Keywords: Contract Employment, Employee Commitment, Work Initiative, Job Satisfaction, Ghana Shippers Authority

\section{Introduction}

Contract employment has never been predominant than in recent years, although not a new concept, it's widespread has been extensively documented. Godfrey (2018) noted that contract employment continues to receive much attention as a result of the indefatigable changes that has characterized working structures across the globe. These changes have led to some organizations opting to hire employees on short term or long term contract basis, while some employees motivated by their career objectives have also settled for short term contracts at the expense of long term or permanent employment (Keim, Landis, Pierce \& Earnest, 2014). Contract employment
\end{abstract}


cuts across various sectors, from academia to industries, to government agencies and private enterprises (Waaijer, Belder, Sonneveld, van Bochove \& van der Weijden, 2017) with fresh graduates mostly caught up in the web of contract employment around the world.

The practice of organizations employing on contract basis has been importunate due to the pressure of profit maximization in the face of globalization and as a result, adopt flexible work schedules that make the organization more profitable (Cappelli \& Keller, 2013). It has been noted however, that organizations use contract employment to escape from the cost associated with permanent employment while other organizations use the contract period to drill the employees into the culture of the organization for permanent employment in the near future (Pedulla (2013). Ongera and Juma (2015) observed that contract employment immune organizations from some tax liabilities, while at the same time providing more flexible work schedule.

In spite of the numerous reasons put forward by these organizations, little is said of how some contract employees are denied their basic right. Some of these contract employees are barred from joining trade unions to bargain for better employment conditions (Godfrey, 2018). Others also leave with the skills they acquire which affect the organization negatively as the organization would have to spend money to train new employees it would hire (Bertrand-Cloodt, Corvers, Kriechel \& Van-Thor, 2012). In the past, contract employment was taken up during internship or when an employee is on leave, but the trend has shifted in recent times. Contract workers in recent times take up managerial positions in areas where their expertise are much needed (Ntisa, Dhurup \& Joubert, 2016).

Employees put on different attitude at the workplace partly due to the category of employment conditions they find themselves. A permanent employee is more likely to be satisfied than a contract employee. Permanent employees enjoy statutory benefits like pension, insurance, paid leave which culminate into a positive work outcome, commitment and behaviour (Tinuke, 2012). This can however not be said for the contract employees. These contract employees may not be motivated as compared to permanent employees. Some organizations see contract employees as peripherals and as such do not invest so much in training these employees.

In Ghana, some government organizations have switched to employing workers on contract basis, especially when the country was under the International Monetary Fund (IMF) programme. Other companies also attribute contract employment to the energy crisis which crippled the country between 2014 and 2016. For instance, Gold Fields Ghana Ltd. had to lay off 700 workers and asked them to reapply as contract employees. Similarly, Coca-Cola Ghana Ltd. sent home about 200 workers and requested them to reapply as contract employees (Iko, 2015). The Ghana Shippers' Authority (GSA) like most government organizations in recent times hires employees on contract basis through Rakes Company Limited. These employees are mostly offered six months to one year contract which are sometimes renewed at the end of the period. These contract employees are regarded as peripherals to the Ghana Shippers' Authority as they do not enjoy most of the benefits offered to the permanent employees. These contract employees are denied clothing allowance, overtime allowance and training. In spite of this, the GSA expects the contract employees to show commitment and be passionate about their jobs. Organizational studies have shown that employees who perceive they are unfairly or unequally treated do not put up their best at the work place (Tinuke, 2012; Landsbergis, Grzywacz \& LaMontagne 2014). Findings of existing studies have divergent perspectives with respect to contract employment and employees' behaviour.

Objectives of the research 
This study was guided by the following objectives:

- To ascertain the effect of contract employment on employees' commitment.

- To determine the effect of contract employment on employees' work initiative.

- To find out the effect of contract employment on employees' job satisfaction.

- To compare the differences between the behaviour of contract and permanent employees at the Ghana Shippers Authority.

\section{Overview of Literature}

\section{Contract Employment}

Contract employment is a contract in which a company hires an employee for a specific period of time. In most cases, contract employment is for a year but can be renewed after the term expires depending on the requirement (Bassanini \& Cingano, 2017). In most contract employment, the employee is not on the payroll of the company. Lindahl-Norberg, Montgomery, Bottai, Heyman and Hovén (2017) described contract employment as one which the pay-out or the payment is fixed in advance and is not altered till the term expires. However, Deininger, Nagarajan, and Singh (2016) assert that such contracts cannot be given for routine jobs. It is usually given out for jobs which are temporary. It cannot be used to replace an existing employee if he or she is on a long leave. In other institutions, sometimes professionals are hired on contractual basis to complete a specific project. They could be absorbed in the company later when the project is completed (Caliendo, Fedorets, Preuss, Schröder \& Wittbrodt, 2018).

Contract employment normally applies to jobs that do not fit the traditional narrative of permanent jobs. These contracts are normally taken up on short or long-term basis. The contracts are normally guided by dates/periods in which the contract ends upon the expiration of the date or the completion of the project in which the contract is tied to (Wandera, 2011). Normally, these contract employees are hired by recruiting agencies on behalf of organizations, although organizations sometimes hire them for specific assignments such as consultancy. In the event of organizations hiring the contract employees themselves, they normally tie the contract date, thus the expiration of the contract to the execution of the assignments for which the short-term employees were employed (Ntisa et al., 2016). The organization and the contract employee are normally at will to terminate the contract when there is a breach by a party to the contract.

The duration for contract employment differs across countries. For instance, it is enshrined in Germany's labour law that short term contracts should not go beyond 2 years whereas South Africa has pecked the duration to not more than five years. In Nigeria, however, there is no fixed duration for contract employment as is also the case with Ghana (Waaijer, Belder, Sonneveld, van Bochove \& van der Weijden, 2017). The Ghana Labour Act 2003, (Act 651) has not provided a fixed duration for contract employment, but largely endorses contract employment as a formal employment. From most organizations' point of view, contract employment is advantageous to them as they view it as a cost saving tool (Wandera, 2011). Organizations sometimes consider contract employees as marginal and as such do not spend so much on training and developing them (Cabrales, Dolado \& Mora, 2014). Some even go to the extent of not paying social security and overtime allowances to the contract employees. What these organizations, however, fail to recognize is the cost they incur in acclimatising these employees to the culture of the organization. Once the contract ends, these 
employees go with all the skills they may have acquired from the organization as they move to a different organization or assignment.

In the minds of some contract employees, this form of contract is a blessing to them (Waaijer et al., 2017). The contract period may give them time to advance or climb the academic ladder, it also presents an opportunity for further skills advancement or development or acquisition as well as an opportunity to move into newer organizations or higher assignments. There is also the issue of not getting so attached to a particular organization which will require their loyalty and commitment sometimes at the expense of their personal goals. To some, contract employment is a way to transition from an unemployment position to a temporal employment while they navigate for a better employment option. The analysis above shows that contract employees may have the tendency to behave differently depending on their motives for enrolling on the contract.

Wandera (2011) has shown that employers mainly hire contract employees for three main reasons namely; staffing flexibility, cost reduction and ease of dismissal.

Staffing flexibility: Innovation, competition and technology has forced companies to rethink their employment policies by creating room for temporal employees who may fit into the organization at a particular point in time (Godfrey, 2018). This makes businesses flexible, while at the same time meeting their organizational needs. At any given point in time, most organizations will have a mix of contract and permanent employees which will result in a more efficient and effective workplace. As a result of the uncertain nature of businesses, most organizations prefer to hire contract employees when there is excess demand of work (Ongera \& Juma, 2015).

Cost reduction: Generally, it is believed that hiring contract employees is cheaper than permanent employees especially when the recruitment process is done by an agency. Most of these agencies bear the burden of recruiting, screening and hiring workers and paying insurance compensation. This cost reduction argument has however, been shot down in some countries. For instance, studies in UK and Greece could not support the cost reduction assertion. Those studies were of the view that contract employees could increase the marginal cost of the organization, as each additional shortterm employee hired will come with an additional cost (Wandera, 2011).

Ease of dismissal: Most organizations prefer the services of contract employees as a result of the ease with which those employees can be dismissed. With demand in some industries always fluctuating, employers will prefer to hire temporal staff to match up excess demand and lay them off once demand is normalized (Iko, 2015). This means that, organizations will hire such employees as they are needed, thereby giving those organizations some flexibility to bring in new talents.

\section{Employee Commitment}

In today's work environment, employee commitment is one of the key factors accounting for the success of most organizations. It will be seemingly impossible for an organization to reach higher heights without committed labour force (Shahid \& Azhar, 2013). This has led to various studies being carried out to examine the relationship between employee commitment and performance, employee commitment and retention etc. (Dartey-Baah, 2016). Various scholars have tried to explain what employee commitment means, for instance, Dartey-Baah (2016) explained employee commitment as a process by which the goals of the employee and that of the organization becomes compatible, thus there is an alignment in the goals of both parties. Zheng as cited by (Irefin \& Mechanic, 2014) also explained the phenomenon as employee's attitude toward an organization. Meyer and Maltin (2010) also defined it as "a force that binds an individual to a target and to a course of action of 
INTERNATIONAL JOURNAL OF ACADEMIC RESEARCH IN BUSINESS AND SOCIAL SCIENCES Vol. 10, No. 5, May, 2020, E-ISSN: 2222-6990 @ 2020 HRMARS

relevance to that target group". The above definitions point to one thing, that commitment makes it possible for an employee to be identified with an organization. Meyer, Stanley and Parfyonova (2012) however, gave a comprehensive definition of employee commitment. They defined employee commitment using a multi-dimensional approach. They considered commitment to have an affective, normative and continuance perspectives.

Affective Commitment: this is when some employees view their relationship with their organization in terms of their value and goals similarity with the organization. These employees' commitment is derived from the compatibility of their personal goals with that of their organization. This presupposes that the extent to which an employee sees his or her personal goals aligning with that of the organization will go a long way to influence his or her decision to stay with the organization (Bandula \& Lakmini, 2016). If a contract employee feels his or her personal goals are in line with that of the organization, the contract employee will be more inclined to be committed to the organization than one whose goals and values differs from that of the organization.

Normative Commitment: refers to the willingness of an employee to stick with an organization premised on loyalty, a sense of duty or moral obligation. When an employee feels the need to leave an organization, he or she is constrained because of a sense of moral obligation to the organization (Shahid \& Azhar, 2013). Such employees feel indebted to the organization and as such are unwilling to leave the organization.

Continuance Commitment: In situations where employees feel the cost involved in leaving their organization for another organization is high, such employees may be tempted or are likely to stick with their organization (Owusu, 2014). When employees feel there is no better job out there, they may have the tendency to stick with their current jobs especially those with high continuance commitment levels. The question is whether these employees will work their heart out for the organization (Dartey-Baah, 2016). This is because the employee may be dissatisfied with his or her job but is forced to stick around due to his or her continuance commitment. Bandula and Lakmini (2016) found a positive relationship between continuance commitment and job performance.

In Kenya, Wandera (2011) conducted a study to determine the effect of contract employment on the commitment of employees in the Kenya Forest Service. Using the case study approach, the study found that contract employees exhibited some levels of divided allegiance and as a result were less committed to their jobs as compared to their permanent colleagues. Jandaghi, Mokhles and Bahrami (2011) however, found that both contract and permanent employees showed almost the same levels of commitment to their jobs. In furtherance to this, Dačiulytè and Aranauskaitè (2012) investigated the relationship between contract employees and the three types of organizational commitment (affective, continuance and normative). The result of the study indicated a moderate correlation between contract employees and their commitment to the organization. Though these employees were positive about their work environment, they were not enthused with the lack of career development opportunities in their organizations.

It is important to note that, not every study has found negative consequences associated with contract employment. Jafri and Lhamo (2013) however, proved that contract employees were seen to be more committed than their permanent counterparts. The reason given by the authors to this result was that, contract employees desire to perform better to be considered for permanent employment. For the permanent employees, their career enthusiasm may have diminished; hence, they exhibit low commitment which also affects their job performance. Rousseau (2010) observed that contract employees seeking a long-term relationship with their organizations, even when 
INTERNATIONAL JOURNAL OF ACADEMIC RESEARCH IN BUSINESS AND SOCIAL SCIENCES Vol. 10, No. 5, May, 2020, E-ISSN: 2222-6990 @ 2020 HRMARS

maintaining a transactional psychological contract, showed a more relational interaction with their employers, resulting in higher levels of commitment to their organization. Engellandt and Riphahn (2005) observed even a higher level of employee effort in contract workers compared to permanent ones. The authors argue that contract workers are more likely to work harder, although this performance level is more commonly found among employees that have a possibility of going upwards in the organization. Feldman (2006) found similar results, pointing out that contract workers with expectations of future permanent employment are more likely to perform at higher levels and show more commitment to work compared to those who do not have these expectations.

\section{Employee Initiatives}

Employee initiative has been described by Hong, Liao, Raub and Han (2016) as employee's ability to assess and bring out ideas independently. Wihler, Ellen III, Hochwarter and Blickle (2017) view employee personal initiative as proactive work behaviour defined as anticipatory action that employees take to impact on their environment. Employee initiative is considered as the power or opportunity to act or take charge before others do. According to Frese and Fay (2001), there are three aspects of employee's personal initiative namely; self-starting, pro-active and persisting. To them, people exhibit classes of behaviours and as such employee initiative is viewed as an active behaviour. Self-starting implies that a person does something without being told, without getting an explicit instruction or without an explicit role requirement. Pro-activity means to have a long-term focus on work to respond to demands (Presbitero, 2015). Long-term focus on work enables the individual to consider things to come (new demands, new or reoccurring problems and emerging opportunities) and to do something proactively about them. Thus, problems and opportunities are anticipated, and are dealt with immediately they occur. When taking initiative, persistence is usually necessary to reach one's goal. Generally, employee initiative implies that something is changed: a process, a procedure, or a task is added or modified (Vough, Bindl \& Parker, 2017). Taking initiative requires self-setting goal. This goal can be based on a personally developed idea, taking charge of an idea or a project that is known but has not been put into action in before. Frese and Fay (2011) examined the differences between permanent and contract employees in terms of their personal initiative in India. Using correlational analysis, the study found that personal initiative was low among contract employees as compared to their permanent counterpart. This lower employee initiative was seen to sharpen and modify the concepts of reciprocal determinism, organizational citizenship behaviour, innovation, entrepreneurship, work performance and self-regulation on the part of the contract employees.

Contract employment is associated with greater, subjective and objective job insecurity due to a heightened unemployment risk since contract end dates are explicitly specified, and also because employment protection is less strict for such contracts. In turn, greater job insecurity has negative effect on psychological well-being, because the planning of current and future life activities is constrained (Gash, Mertens \& Romeu-Gordo, 2010). Scherer (2009) found evidence of a strong relationship between job insecurity feelings and stress, while job insecurity has also been linked with work-family conflict and a deterioration of family life that can lead to less satisfaction and personal wellbeing. In their investigation into contract employment and individual's subjective wellbeing, Dawson, Veliziotis and Hopkins (2014) discovered a large proportion of differences in self-reported wellbeing between contract and permanent employees. 
INTERNATIONAL JOURNAL OF ACADEMIC RESEARCH IN BUSINESS AND SOCIAL SCIENCES Vol. 10, No. 5, May, 2020, E-ISSN: 2222-6990 @ 2020 HRMARS

\section{Job Satisfaction}

Job satisfaction is the appraisal involving various aspects of work such as career prospects, working conditions and remuneration. The outcome of such appraisal always determines how satisfied or dissatisfied an employee will be (Godfrey, 2018). Owusu (2014) described job satisfaction to be a pleasurable or positive emotional state emanating from appraising one's work. Employees have personal expectations, when they compare the outcome of their work with their personal expectations there is likelihood that the expectations of these employees would not be met, when this happens the employees become dissatisfied with their work. On the other hand, when the actual outcome of the work matches their (employees) expectations, then they become satisfied. Studies have reported three approaches in measuring job satisfaction: Job Characteristics, Social Information Processing (Organizational Characteristics) and Dispositional Characteristics.

Job Characteristics: The job characteristics approach to job satisfaction opines that the nature of one's work or the characteristics of one's organization is an important factor which can have an impact on the satisfaction level of an employee (Owusu, 2014). These individuals examine the benefits they are getting from the organization with the benefits they expect to receive from the organization, that is comparing expected benefit with actual benefit to inform behaviour (Berge, 2011). Once the benefits conform to their expectation, they become satisfied, on the other hand, they become dissatisfied once their expectations are not met. What these employees do is that they compare aspects of their work such as promotional opportunities, nature of work, recognition, advancement, salary increment and autonomy to determine their level of satisfaction in the organization.

Social Information Processing: Employees are relational beings and sometimes do measure their level of satisfaction with how they relate with other employees or their colleagues. These employees process this relationship and become affected by the outcome of it (Godfrey, 2018). For instance, when an employee perceives his or her co-worker not to be satisfied with his or her work, there is the tendency for the employee who processed such information to also be dissatisfied with his or her work. On the other hand, if an employee perceives his or her co-worker to be satisfied with his or her job, there is the likelihood for that employee to be satisfied with his or her own work. This shows that job satisfaction in this case is premised on how employees relate with their colleagues.

Dispositional Characteristics: This approach relies on the disposition of the employees. The dispositional approach stipulates that some employees are likely to be satisfied or dissatisfied with their work irrespective of the working environment or the nature of the job. Naturally, some employees' genetic makeup makes them have positive disposition towards their work while those with negative genetic makeup are likely to have negative disposition towards their work.

In a United States study, Anwar, Aslam and Tariq (2011) found that contract employees had lower job satisfaction as compared to the permanent employees. Bruno, Caraleo, Dessy (2013) reported that lack of job stability characterised with contract employment was the major cause of low job satisfaction among the young workers in Italy. In assessing the effect of contract employment on the satisfaction of graduates in work settings, Waaijer, Belder, Sonneveld, van Bochove \& van der Weijden, (2017) discovered that those graduates who had been employed on full time basis were more satisfied than those who had been employed on contract basis who were not optimistic about the permanence of their jobs. In a similar study in Ghana, Amankwa (2011) examined the level of satisfaction among contract and permanent employees at Olan Ghana Limited. The result of the study was not different from previous studies. The finding indicated that contract employees were less 
satisfied with their jobs than permanent employees. The dissatisfaction among contract employees stemmed from the fact that, they were not involved in the decision making process of the organization, and elements like career development opportunities did not consider these contract employees.

\section{Research Methodology}

The study was cross-sectional in nature, which made use of the quantitative research approach. The authors utilised the descriptive research design because the study sought to describe the state of affairs with the study population. To minimise cases of biases, a simple random sampling techniques was employed to select 142 employees to participate in the study. Data was collected by way of a structured questionnaire. A five-point Likert scale, ranging from strongly disagree to strongly agree was used to measure the variables (1: Strongly Disagree; 2: Disagree; 3: Undecided; 4: Agree; 5: Strongly Agree).The response rate was 92\%, of 142 questionnaire distributed, 132 were valid responses, therefore, the analysis of the result of the study was based on 132 respondents, of which 62 are contract employees and 70, permanent employees. To ensure reliability and internal consistency of the research instrument, a Cronbach's Alpha reliability coefficient was tested on 35 items, which yielded a coefficient of 0.810 , indicating a reliable research instrument as cited by Field (2009). Ethical issues in research, such as informed consent and confidentiality were ensured. The main statistical tools used for the analysis of the data were Pearson product moment correlation, simple linear regression and an Independent T-Test. Data processing and analysis were done with the use of SPSS version 21. Contract employment was measured using indicators such as employment on specific period, contingency, payment fixed in advanced, not on payroll and no explicit or implicit long-term employment.

\section{Discussion of Findings}

Preliminary analysis was conducted to ensure no violation of the assumption of linearity. The assumption of linearity was tested using the Pearson product moment correlation. As indicated in Table 1, all the variables were significantly and positively related with contract employment, with a Pearson correlation co-efficient of 0.248 for employee commitment $(r=0.248 ; p<0.05)$; 0.369 for personal work initiative $(r=0.369 ; p<0.05)$ and a 0.505 for job satisfaction $(r=0.505 ; p<0.05)$.

Table 1: Correlation Matrix

\begin{tabular}{lll}
\hline Constructs & & $\begin{array}{l}\text { Contract } \\
\text { Employment }\end{array}$ \\
\hline Employee Commitment, & Pearson Correlation & 0.248 \\
& Sig. (2-tailed) & 0.000 \\
Work Initiatives & Pearson Correlation & 0.369 \\
& Sig. (2-tailed) & 0.001 \\
Job Satisfaction & Pearson Correlation & 0.505 \\
& Sig. (2-tailed) & 0.001 \\
\hline
\end{tabular}

Source: Field survey (2019) 
INTERNATIONAL JOURNAL OF ACADEMIC RESEARCH IN BUSINESS AND SOCIAL SCIENCES

Vol. 10, No. 5, May, 2020, E-ISSN: 2222-6990 ㄷ 2020 HRMARS

In order to determine the effect of contract employment on the three variables (employee commitment, work initiative and job satisfaction), a simple linear regression was computed and the coefficient tested. The model used the following statistical equation:

$\mathbf{Y}=\boldsymbol{\beta}_{0}+\boldsymbol{\beta} \mathrm{X}+\boldsymbol{\varepsilon}$

$Y=$ dependent variables (commitment, work initiative and job satisfaction)

$\beta_{0}=$ the constant or the intercept

$\beta=$ the regression coefficient

$\mathrm{X}=$ the independent variable (contract employment).

\section{Contract Employment and Employee Commitment}

Table 2: Model Summary - Effect of Contract Employment on Employees' Commitment

\begin{tabular}{llllc} 
Model & $R$ & R Square & Adjusted R Square & Std. Error of the Estimate \\
\hline 1 & $.248^{\mathrm{a}}$ & .062 & .050 & 6.36559
\end{tabular}

a. Predictors: (Constant), Contract Employment

Evidence from the study showed that contract employment explained 6.2 percent of the variations in employee commitment. The explanatory power, even though small, was found to be significant, with an F statistics of 5.184 and a P-value $=0.000$, as indicated on Tables 2, 3 and 4.

Table 3: ANOVA ${ }^{\mathrm{a}}$ - Effect of Contract Employment on Employees' Commitment

\begin{tabular}{lllllll}
\hline Model & & Sum of Squares & Df & Mean Square & S & Sig. \\
\hline 1 & Regression & 210.069 & 1 & 210.069 & 5.184 & $.025^{\mathrm{b}}$ \\
& Residual & 3201.140 & 79 & 40.521 & & \\
& Total & 3411.210 & 80 & & & \\
\hline
\end{tabular}

A. Dependent Variable: Employees' Commitment

b. Predictors: (Constant), Contract Employment

This result indicates that contract employment can influence the commitment of employees to some extent. This result corroborates with the findings of Dačiulytè and Aranauskaitè (2012) who found contract employment to moderately affect employee commitment. The result of the analysis is illustrated in Table 4.

Table 4: Effect of Contract Employment on Employees' Commitment

\begin{tabular}{|c|c|c|c|c|c|c|}
\hline \multirow{2}{*}{\multicolumn{2}{|c|}{ Model }} & \multicolumn{5}{|c|}{$\begin{array}{l}\text { Standardize } \\
\text { d } \\
\text { Coefficients }\end{array}$} \\
\hline & & B & $\begin{array}{l}\text { Std. } \\
\text { Error }\end{array}$ & Beta & $\mathrm{T}$ & Sig. \\
\hline 1 & (Constant) & 28.791 & 4.496 & & 6.404 & .000 \\
\hline & Contract Employment & .417 & .183 & .248 & 2.277 & .025 \\
\hline
\end{tabular}

a. Dependent Variable: Employees' Commitment

Source: Field survey (2019) 
INTERNATIONAL JOURNAL OF ACADEMIC RESEARCH IN BUSINESS AND SOCIAL SCIENCES

Vol. 10, No. 5, May, 2020, E-ISSN: 2222-6990 ㄷ 2020 HRMARS

\section{Contract Employment and Employees' work initiatives}

Additionally, the study sought to determine the effect of contract employment on employees' work initiative. Employee work initiative is described as employee's ability to assess and bring out ideas independently in relation to the assigned tasks.

Table 5: Model Summary - Effect of Contract Employment on Employees' Work Initiatives

\begin{tabular}{lllll} 
Model & R & R Square & Adjusted R Square & Std. Error of the Estimate \\
\hline 1 & $.369^{a}$ & .136 & .125 & 6.10734
\end{tabular}

\section{a. Predictors: (Constant), Contract Employment}

The linear regression model explained 13.6 percent of the variations in employee work initiative, and the overall effect was statistically significant with an F statistics of 12.454 and a P-value of 0.000 (tables 5, 6 and 7).

Table 6: ANOVA ${ }^{a}$ - Effect of Contract Employment on Employees' Work Initiatives

\begin{tabular}{lllllll}
\hline Model & & Sum of Squares & Df & Mean Square & $F$ & Sig. \\
\hline 1 & Regression & 464.541 & 1 & 464.541 & 12.454 & $.001^{\mathrm{b}}$ \\
& Residual & 2946.669 & 79 & 37.300 & & \\
& Total & 3411.210 & 80 & & & \\
\hline
\end{tabular}

a. Dependent Variable: Employees' Work Initiatives

b. Predictors: (Constant), Contract Employment

This finding point out that contract employment affects the work initiatives of employees. The result of the regression analysis is shown in Table 7. This result presupposes that employees have greater work initiatives when there are no contractual terms with respect to employment than when there is a contract employment. The result supports the finding of Frese and Fay (2011) who also found a significant effect of contract employment on employees' work initiative of employees in India.

Table 7: Effect of Contract Employment on Employees' Work Initiatives

\begin{tabular}{|c|c|c|c|c|c|c|}
\hline & & \multicolumn{2}{|c|}{$\begin{array}{l}\text { Unstandardized } \\
\text { Coefficients }\end{array}$} & \multicolumn{2}{|c|}{$\begin{array}{l}\text { Standardized } \\
\text { Coefficients }\end{array}$} & \multirow[b]{2}{*}{ Sig. } \\
\hline \multicolumn{2}{|c|}{ Model } & B & Std. Error & Beta & $\mathrm{T}$ & \\
\hline 1 & (Constant) & 25.612 & 3.826 & & 6.694 & .000 \\
\hline & $\begin{array}{l}\text { Contract } \\
\text { Employment }\end{array}$ & .869 & .246 & .369 & 3.529 & .001 \\
\hline
\end{tabular}

a. Dependent Variable: Employees' Working Initiatives

Source: Field survey (2019) 
INTERNATIONAL JOURNAL OF ACADEMIC RESEARCH IN BUSINESS AND SOCIAL SCIENCES

Vol. 10, No. 5, May, 2020, E-ISSN: 2222-6990 @ 2020 HRMARS

\section{Contract Employment and Employees' job satisfaction}

The last variable the study examined was contract employment and job satisfaction of employees. In much the same way, a simple linear regression coefficient was computed to estimate the effect size.

Table 8: Model Summary - Effect of Contract Employment on Employees' Job Satisfaction

\begin{tabular}{lllll} 
Model & R & R Square & Adjusted R Square & Std. Error of the Estimate \\
\hline 1 & $.505^{a}$ & .255 & .246 & 5.67197
\end{tabular}

a. Predictors: (Constant), Contract Employment

Data from the study showed contract employment explained 25.5 percent of employees' job satisfaction. With an F statistics of 27.033 and a P-value of 0.000 , the total variance explained was statistically significant (tables 8, 9 and 10).

Table 9: ANOVA ${ }^{\mathrm{a}}$ - Effect of Contract Employment on Employees' Job Satisfaction

\begin{tabular}{lllllll}
\hline Model & & Sum of Squares & df & Mean Square & F & Sig. \\
\hline 1 & Regression & 869.684 & 1 & 869.684 & 27.033 & $.000^{\mathrm{b}}$ \\
& Residual & 2541.526 & 79 & 32.171 & & \\
& Total & 3411.210 & 80 & & & \\
\hline
\end{tabular}

a. Dependent Variable: Employees' Job Satisfaction

b. Predictors: (Constant), Contract Employment

The linear regression model shows that contract employment significantly affect job satisfaction of employees. The finding of the regression model is presented in Table 10. This finding is in congruence with the result of Bruno, Caraleo, Dessy (2013) who reported a significant effect of contract employment on employee job satisfaction. The result also corroborates the finding of Waaijer, Belder, Sonneveld, van Bochove \& van der Weijden, (2017).

Table 10: Effect of Contract Employment on Employees' Job Satisfaction

\begin{tabular}{|c|c|c|c|c|c|c|}
\hline \multirow[b]{2}{*}{ Mode } & & \multicolumn{2}{|c|}{$\begin{array}{l}\text { Unstandardized } \\
\text { Coefficients }\end{array}$} & \multicolumn{3}{|c|}{$\begin{array}{l}\text { Standardized } \\
\text { Coefficients }\end{array}$} \\
\hline & & B & Std. Error & Beta & $\mathrm{T}$ & Sig. \\
\hline \multirow[t]{2}{*}{1} & (Constant) & 28.308 & 2.133 & & 13.274 & .000 \\
\hline & Contract employment & .761 & 146 & .505 & 5.199 & .000 \\
\hline
\end{tabular}

a. Dependent Variable: Employees' Job Satisfaction

Source: Field survey (2019)

The study finally analysed the differences in the behaviour of contract and permanent employees. An Independent t-test was used to measure the differences between the behaviour of contract employees and permanent employees with respect to their commitment, work initiative and job satisfaction. Initially, the study performed a descriptive statistics to compare the means of the two groups. Table 11 exhibits the result of the descriptive statistics. 
INTERNATIONAL JOURNAL OF ACADEMIC RESEARCH IN BUSINESS AND SOCIAL SCIENCES

Vol. 10, No. 5, May, 2020, E-ISSN: 2222-6990 @ 2020 HRMARS

Table 11: Comparative Test between Contract and Permanent Employees

\begin{tabular}{llllll} 
& Status & N & Mean & Std. Deviation & Std. Error Mean \\
\hline C & Contract & 62 & 31.76 & 14.453 & .987 \\
& Permanent & 70 & 33.58 & 13.762 & 1.980 \\
I & & & & & \\
& Contract & 62 & 39.79 & 14.334 & .953 \\
& Permanent & 70 & 41.59 & 13.020 & 1.089 \\
JS & Contract & 62 & 39.76 & 13.757 & 1.336 \\
& & & & & \\
& Permanent & 70 & 43.66 & 14.636 & 1.336 \\
& & & & & \\
\hline
\end{tabular}

Source: Field survey (2019) $(C=$ commitment, $\mathrm{l}=$ initiative, JS = job satisfaction)

With regards to employee commitment, contract employees had a mean and standard deviation of $(M=31.76$; $S t d .=14.453)$ which was lower, compared to their permanent counterpart $(M=33.58 ; S t d .=13.762)$. The mean and standard deviation for personal initiative was also lower for contract employees than the permanent employees $(M=39.79 ;$ Std. $=14.334)$ and $(M=41.59$; Std. $=13.020)$. With job satisfaction, contract employees had a mean and standard deviation of ( $M=39.76$; $S t d .=13.757)$ compared to the permanent staff $(M=43.66$; $S t d .=14.636)$. 
INTERNATIONAL JOURNAL OF ACADEMIC RESEARCH IN BUSINESS AND SOCIAL SCIENCES Vol. 10, No. 5, May, 2020, E-ISSN: 2222-6990 @ 2020 HRMARS

Table 12: Independent Sample T-Test

\begin{tabular}{|c|c|c|c|c|c|c|c|c|}
\hline & & $\begin{array}{l}\text { Levene } \\
\text { for Equ } \\
\text { Varian }\end{array}$ & $\begin{array}{l}\text { 's Test } \\
\text { uality of } \\
\text { ces }\end{array}$ & & t-test fo & Equality & Means & \\
\hline & & $\mathrm{F}$ & Sig. & $\mathrm{T}$ & Df & $\begin{array}{l}\text { Sig. (2- } \\
\text { tailed) }\end{array}$ & $\begin{array}{l}\text { Mean } \\
\text { Difference }\end{array}$ & $\begin{array}{l}\text { Differ } \\
\text { ence }\end{array}$ \\
\hline \multirow[t]{2}{*}{ C } & $\begin{array}{l}\text { Equal } \\
\text { variances } \\
\text { assumed }\end{array}$ & 5.14 & .061 & 0.331 & 101 & .175 & 2.0232 & 3.305 \\
\hline & $\begin{array}{l}\text { Equal } \\
\text { variances not } \\
\text { assumed }\end{array}$ & & & .627 & 16.4 & .578 & 2.0232 & 3.566 \\
\hline \multirow[t]{2}{*}{ I } & $\begin{array}{l}\text { Equal } \\
\text { variances } \\
\text { assumed }\end{array}$ & 5.31 & .145 & 1.210 & 101 & .162 & 2.0232 & 3.305 \\
\hline & $\begin{array}{l}\text { Equal } \\
\text { variances not } \\
\text { assumed }\end{array}$ & & & .423 & 16.4 & .578 & 2.0232 & 3.566 \\
\hline \multirow[t]{2}{*}{ JS } & $\begin{array}{l}\text { Equal } \\
\text { variances } \\
\text { assumed }\end{array}$ & 3.71 & .506 & 0.331 & 101 & .125 & 2.0232 & 3.305 \\
\hline & $\begin{array}{l}\text { Equal } \\
\text { variances not } \\
\text { assumed }\end{array}$ & & & .132 & 16.4 & .578 & 2.0232 & 3.566 \\
\hline
\end{tabular}

Source: Field survey (2019) (C= commitment, I= initiative, JS = job satisfaction)

An Independent t-test was computed to find the differences in the behaviour of contract and permanent employees at the Ghana Shippers' Authority. Evidence from the analysis revealed that the behaviour of contract employee with respect to commitment, work initiative and job satisfaction was not significantly different from the behaviour of permanent employees, as the P-values of commitment, work initiative and job satisfaction exceeded 0.05 . This result did not confirm that of Rousseau (2010) who observed a significant difference in the commitment of contract staff than that of permanent staff. The finding again did not support the results of Wandera (2011) who found that permanent employees were more committed to their jobs than their contract counterparts. Moreover, this study was not in agreement with the results of Engellandt and Riphahn (2005) who observed a higher commitment of contract workers compared to permanent worker, neither did our study corroborates the finding of Waaijer et al (2017), who also discovered that contract employees were less satisfied with their job than their permanent counterparts. 


\section{Conclusion and Implications}

This study has provided an empirical overview and relevant discussion on contract employment, employee commitment, work initiatives and job satisfaction, and their relationships at the Ghana Shippers' Authority. The paper focused on predicting the effect of contract employment on employee commitment, work initiative and job satisfaction. Though the prediction for contract employment on the variables was strong, the coefficient of determination explaining the variances between the variables was either moderate or weak. Overall, the study found significant effect of contract employment on employee commitment, work initiatives and job satisfaction. Therefore, this study concludes that contract employment significantly predicts employees' commitment, work initiatives and job satisfaction. Though extant literature has discovered inconsistent reports on the relationship between the study variables, this study found a positive relationship between contract employment and the variables analysed. The study however, did not find any significant differences between the behaviour of contract employees and permanent employees as reported by various studies. These differences in empirical findings could be ascribed to the differing environmental, social and work structures pertaining in different organizational settings and the various contexts within which these studies take place. The study thus recommends that, management of Ghana Shippers Authority enriches the contractual engagement of employees so as to bring the best in them to be committed to the organisation. Moreover, employees, (especially those on contract) should be encouraged to bring in new ideas into the organisation. The study finally recommends the need to conduct more empirical studies to unveil the factors that account for the differing research findings with respect to the behaviour of contract and permanent employees to enhance managerial decision making and the management of employees in general.

\section{Contribution to Knowledge}

The contributions of this research to knowledge stem from two angles: theoretical and contextual. Theoretically, the study supports Social Comparison theory and the Effort-Reward Model. The Social comparison theory proposes that employees' reactions are monitored by their perception of fairness. Additionally, the Effort-Reward model postulates that, when employees perceive that their effort and reward are mismatched, their behaviour in terms of commitment, work initiative, wellbeing and satisfaction decreases. The findings of this study confirms these two theories, as contract employees at Ghana Shippers Authority perceive that they are treated as peripherals in the organisation and as such, are not part of decisions like training and development which is enjoyed by their permanent counterpart. Contextually, most empirical studies on the behaviour of contract and permanent workers have been conducted in the developed world, and even those in Ghana basically focused on mining firms. Thus the conduct of this study brings to light, the knowledge of the behaviour of contract and permanent workers in the Ghana Shipping Authority. This study is important as the management of Ghana Shippers Authority can use the findings to enhance their contractual terms to boost the commitment, initiative and the satisfaction of contract workers.

\section{References}

Amankwa, Y. (2011). Assessment of employee satisfaction at Olam Ghana limited. Unpublished doctoral dissertation, University of Cape Coast, Ghana. 
INTERNATIONAL JOURNAL OF ACADEMIC RESEARCH IN BUSINESS AND SOCIAL SCIENCES

Vol. 10, No. 5, May, 2020, E-ISSN: 2222-6990 @ 2020 HRMARS

Anwar, M. S., Aslam, M., \& Tariq, M. R. (2011). Temporary job and its impact on employee performance. Global Journal of Management and Business Research, 11(8), 1-7.

Bandula, P. M. K. U., \& Lakmini, V. K. J. (2016). Impact of employee commitment on job performance: based on leasing companies in Sri-Lanka. International Journal of Arts and Commerce, 5(8), 822.

Bassanini, A., \& Cingano, F. (2017). Before it gets better: The short-term employment costs of structural reforms, IZA Discussion Paper no. 9187, Institute for the Study of Labour, Germany.

Berge, M. (2011). Group work and physics: characteristics, learning possibilities and patterns of interaction. Unpublished doctoral dissertation, Chalmers University of Technology, Sweden .

Bertrand-Cloodt, D., Corvers, F., Kriechel, B., \& Van Thor, J. (2012). Why do recent graduates enter into flexible jobs? De Economist, 160(2), 157-175.

Bruno, G. S., Caroleo, F. E., \& Dessy, O. (2013). Stepping stones versus dead end jobs: Exits from temporary contracts in Italy after the 2003 reform. Rivista Internazionale di Scienze Sociali, 121(1), 31-62.

Cabrales, A., Dolado, J. J., \& Mora, R. (2014). Dual Labour Markets and (Lack of) On-the-Job Training: PIAAC Evidence from Spain and other EU countries, IZA Discussion Papers No. 8649, Institute for the Study of Labour (IZA), Germany.

Caliendo, M., Fedorets, A., Preuss, M., Schröder, C., \& Wittbrodt, L. (2018). The short-run employment effects of the German minimum wage reform. Labour Economics, 53, 46-62.

Cappelli, P., \& Keller, J. R. (2013). Classifying Work in the New Economy. Academy of Management Review, 38 (4), 575-596.

Daciulyte, R., \& Aranauskaite, A. (2012). Temporary employees' organizational commitment and its determinants : analysis of temporary agency workers. Human resources management and ergonomics (HRM \& E), 6(2), 31-44. .

Dartey-Baah, K. (2016). Goal integration through transformational leadership: a panacea to Ghana's public sector corruption menace. Journal of Global Responsibility, 7(1), 4-25.

Dawson, C., Veliziotis, M., \& Hopkins, B. (2014). Assimilation of the 'migrant work ethic'. Economics Working Paper Series, 1407, University of the West of England, Briston.

Deininger, K. W., Nagarajan, H. Krishnan., Singh S. K. (2016). Short-term effects of India's employment guarantee program on labor markets and agricultural productivity (English). Policy Research working paper; no. WPS 7665; Paper is funded by the Strategic Research Program (SRP). Washington, D.C. : World Bank Group .

Engellandt, A., \& Riphahn, R. T. (2005). Temporary contracts and employee effort. Labour Economics, 12(3), 281-299.

Feldman, D. C. (2006). Toward a new taxonomy for understanding the nature and consequences of contingent employment. Career Development International, 11(1), 28-47.

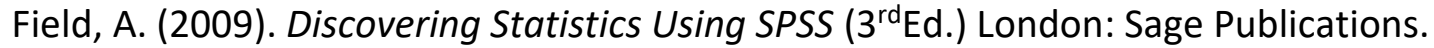

Frese, M., \& Fay, D. (2001). 4. Personal initiative: An active performance concept for work in the $21 \mathrm{st}$ century. Research in Organizational Behaviour, 23, 133-187.

Gash, V., Mertens, A., Romeu, G. L., (2010), Women between part-time and full-time work: The influence of changing hours of work on happiness and life-satisfaction, SOEP Papers on Multidisciplinary Panel Data Research 268, DIW Berlin, The German Socio-Economic Panel (SOEP). 
INTERNATIONAL JOURNAL OF ACADEMIC RESEARCH IN BUSINESS AND SOCIAL SCIENCES

Vol. 10, No. 5, May, 2020, E-ISSN: 2222-6990 @ 2020 HRMARS

Godfrey, A. (2018). The influence and impact of long-term and short-term contracts on employee behaviour - A study of Nigeria's banking industry. International Journal of Economics, Commerce and Management, 6(12), 1-13.

Hong, Y., Liao, H., Raub, S., \& Han, J. H. (2016). What it takes to get proactive: An integrative multilevel model of the antecedents of personal initiative. Journal of Applied Psychology, 101(5), 687.

Iko, C. D. (2015). Job Insecurity, Psychological Wellbeing and Safety Compliance in Steel Manufacturing Company. Unpublished doctoral dissertation, University of Ghana, Ghana.

Irefin, P., \& Mechanic, M. A. (2014). Effect of employee commitment on organizational performance in Coca Cola Nigeria Limited Maiduguri, Borno state. Journal of Humanities and Social Science, 19(3), 33-41.

Jafri, M. H., \& Lhamo, T. (2013). Organizational commitment and work performance in regular and contract faculties of Royal University of Bhutan. Journal of Contemporary Research in Management, 8(2), 47.

Jandaghi, G., Mokhles, A., \& Bahrami, H. (2011). The impact of job security on employees' commitment and job satisfaction in Qom municipalities. African Journal of Business Management, 5(16), 6853-6858.

Keim, A. C., Landis, R. S., Pierce, C. A., \& Earnest, D. R. (2014). Why do employees worry about their jobs? A meta-analytic review of predictors of job insecurity. Journal of Occupational Health Psychology, 19(3), 269-282.

Landsbergis, P. A., Grzywacz, J. G., \& LaMontagne, A. D. (2014). Work organization, job insecurity, and occupational health disparities. American journal of industrial medicine, 57(5), 495-515.

Norberg, L. A., Montgomery, S. M., Bottai, M., Heyman, M., \& Hovén, E. I. (2017). Short-term and long-term effects of childhood cancer on income from employment and employment status: A national cohort study in Sweden. Cancer, 123(7), 1238-1248.

Meyer, J. P., \& Maltin, E. R. (2010). Employee commitment and well-being: A critical review, theoretical framework and research agenda. Journal of Vocational Behavior, 77(2), 323-337.

Meyer, J. P., Stanley, L. J., \& Parfyonova, N. M. (2012). Employee commitment in context: The nature and implication of commitment profiles. Journal of Vocational Behavior, 80(1), 1-16.

Ntisa, A. A., Dhurup, M., \& Joubert, P. A. (2016). The contract of employment status and its influence on the job satisfaction of academics within South African universities of technology. International Journal of Social Sciences and Humanity Studies, 8(2), 180-195.

Ongera, R. M., \& Juma, D. (2015). Influence of temporary employment on employee performance: A case study of Safaricom Limited. International Journal of Business and Commerce, 4(4), 1-37.

Owusu, B. (2014). An assessment of job satisfaction and its effect on employees' performance: A case of mining companies in the Bibiani-Anhwiaso-Bekwai District in the Western Region. Unpublished master's thesis, Kwame Nkkrumah University of Science and Technology, Ghana.

Pedulla, D. S. (2013). The hidden costs of contingency: Employers' use of contingent workers and standard employees' outcomes. Social forces, 92(2), 691-722.

Presbitero, A. (2015). Proactivity in career development of employees: The roles of proactive personality and cognitive complexity. Career Development International, 20(5), 525-538.

Rousseau, D. M. (2010). The Individual-Organisation Relationship: The Psychological Contract. Journal of Occupational and Organisational Psychology, 74,511-541.

Scherer, S. (2009). The social consequences of insecure jobs. Social Indicators Research, 93(3), 527547. 
INTERNATIONAL JOURNAL OF ACADEMIC RESEARCH IN BUSINESS AND SOCIAL SCIENCES

Vol. 10, No. 5, May, 2020, E-ISSN: 2222-6990 @ 2020 HRMARS

Shahid, A., \& Azhar, S. M. (2013). Gaining employee commitment: Linking to organizational effectiveness. Journal of Management Research, 5(1), 250-268.

Tinuke, M. (2012). Employment casualization and degradation of work in Nigeria. International Journal of Business and Social Science, 3(9), 42-59.

Vough, H. C., Bindl, U. K., \& Parker, S. K. (2017). Proactivity routines: The role of social processes in how employees self-initiate change. Human Relations, 70(10), 1191-1216.

Waaijer, C. J., Belder, R., Sonneveld, H., van Bochove, C. A., \& van der Weijden, I. C. (2017). Temporary contracts: Effect on job satisfaction and personal lives of recent PhD graduates. Higher Education, 74(2), 321-339.

Wandera, H. T. (2011). The effects of short term employment contract on an organization: A case of Kenya Forest Service. International Journal of Humanities and Social Science, 1(21), 184-204.

Wihler, A., Ellen III, B. P., Hockwarter, W. A., \& Blickle, G. (2017). Personal Initiative and Job Performance Evaluations. Journal of Management, 43(5), 1388-1420. 